\section{Acto Physica}

Acta Physica, devoted to the publication of original research work in the field of theoretical and experimental physics, is published by the Hungarian Academy of Sciences. Contributions deal with theoretical problems of the principles and applications of quantum mechanics, quantum chemistry, solid-state physics, thermodynamics and statistical mechanics, elementary particles, and experimental investigations in spectroscopy, crystal physies and nuclear and elementary particlo physics. Papers are printed in English, German, French or Russian, with abstracts in various languages. Beginning in 1966, Acta Physica will appear in two volumes annually, each containing approximately four hundred pages, with four issues per volume. The subscription rate per volume

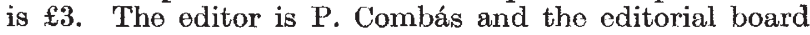
consists of Z. Gyulai, L. Jánossy, L. Kovács and K. Novobátzky.

New Members of the Advisory Council on Technology

Mr. D. K. Fraser, of G. A. Harvey and Co. (London), Ltd., and Mr. A. Siddall, of Joseph Lucas, Ltd., have been appointed members of the Advisory Council on Technology. They replace Lord Brown, who resigned on appointment as Minister of State at the Board of Trade, and Prof. M. J. Lighthill, who resigned on appointment as Honorary Physical Secretary of the Royal Society.

Scholarship at the National Vegetable Research Station

Applications are invited by the National Vegetable Research Station for a postgraduate scholarship tenable at the Station from October 1 . The purpose of the scholarship is to enable the recipient to pursue further studies and to obtain training in one of the following lines of resoarch in progress at the Station: biochemistry; biometry; ecology and control of weeds; entomology; plant pathology. The scholarship, which is of the value of $£ 600$ per annum, will be awarded for two years, with possible extension for a third year. Further information can be obtained from the Secretary, National Vegetable Research Station, Wellesbourne, Warwick. The closing date for receipt of applicaticns is March 31.

\section{Smithson Bicentennial Addresses}

THE Smithsonian Institution has announced that the eleven addresses delivered at the scholarly sessions of the James Smithson bicentennial celebration, held in Washington, D.C., during September 16-18, 1965 (Nature, 208,$320 ; 1965$ ), are to be published in a volume now in the press. The collection will include papers by James S. Bruner, Herbert Butterfield, Sir Kenneth Clark, Ian MeTaggart Cowan, G. Evelyn Hutchinson, Arthur Koestler, Claude Lévi-Strauss, Lewis Mumford, J. Robert Oppenheimer, Stephen E. Toulmin, and Fred L. Whipple, together with an introductory essay by S. Dillon Ripley, secretary of the Smithsonian. Readers of Nature have already had the benefit of a preview of a fow of the papers $(208,923,1033,1036,1145 ; 1965$; and 209, 10; 1966). The book is scheduled for publication in the spring of 1966 by Simon and Schuster, New York, in association with the Smithsonian Institution. Further information can be obtained from the Editorial and Publications Division, Smithsonian Institution, Washington, D.C.

\section{University News:}

Birmingham

Mr. M. H. Lorexto has boen appointed lecturer in the Dopartment of Physical Metallurgy. Dr. G. Sweeney has been appointod sonior Research Fellow in the Dopartment of Mechanical Engincering. The following Research Fellows have also been appointed: Mr. D. K. Davies (geology); Mr. J. A. F. Wickramasinghe (physiological chemistry).
Liverpool

Prof. D. HuLl, professor of physical metallurgy, has been appointed to the Henry Bell Wortley chair of metallurgy, on the resignation of Prof. W. S. Owen. The following lecturers have also been appointed: Mr. K. G. Evans, Dr. G. R. Jones and Mr. D. P. Sen Gupta (olectrical engineering and electronics).

Manchester

DR. J. G. DAVIES, reader in radio astronomy, has been appointed to an additional chair of radio astronomy.

Sheffieid

The following lecturers have beon appointed: Dr. J. D. Harry (physiology); Dr. G. M. Birtwistle (electronic computation in the Department of Applied Mathematics).

Sussex

THe following appointments have been made: Professor. ships: Mr. J. F.C. Kingman (mathematics and statistics); Dr. F. J. Bayley (mechanical engineering); Lectureship: Dr. S. Shall (biological sciences); Senior Research Fellow. ships: Dr. M T. Gillies and Dr. K. A. Stacey (biological sciences).

\section{Announcements}

Mr. J. F. Gatrens has been appointed technical assistant to the scientific director of the Universities Federation for Animal Welfare.

Prof. T. F. Dixon has resigned from his position as head of the Department of Biochemistry in the University of Singapore in order to join the Eastern Mediterranean Region of the World Health Organization.

A seminar on "Atmospheric Physics" will be held by the American Institute of Physics in Washington on March 14. Further information can be obtained from Eugene H. Kone, American Institute of Physics, 335 East 45 Street, New York 17.

A Conference on "Historical Aspects of Microscopy" will be held by the Royal Microscopical Society at Oxford on March 18. Further information can be obtained from the General Secretary, Royal Microscopical Society, Tavistock House South, Tavistock Square, London, W.C.1.

THE 1965 Guthrie Lecture of the Institute of Physics and the Physical Society will be delivered by Dr. J. B. Adams (director of the Culham Laboratory) on the subject "Nuclear Fusion Research" on March 28. Further information can be obtained from the Meetings Officer, Institute of Physics and the Physical Society, 47 Belgrave Square, London, S.W.1.

A MEETING of the Biochemical Society will be held at the University of Hull during March 24-25. The programme will include a colloquium on "The Metabolism of $\mathrm{C}_{1}$ Compounds", a discussion forum on "Mucopolysaccharides", and a visit to the Biological Laboratories of Reckitt and Sons, Ltd. Further information can be obtained from the Administration Officer, the Biochemical Society, 20 Park Crescent, London, W.1.

THE anniversary meetings of the Chemical Society will be held in Oxford during March 28-31. The programme will include symposia on complexes of the heavy donor atoms, contemporary topics in organic chemistry and methods of studying molecular interactions in gases, liquids and solids, a discussion on the uses of programmed learning in the teaching of chemistry to degree standard, the Robert Robinson Lecture on "Some New Developments in the Chomistry of Natural Colouring Matters", to be delivered by Lord Todd, and various tour's and visits. Further information can be obtained from the General Secretary, the Chemical Society, Burlington House, London, W.1. 